\title{
Why Nature \& Nurture Won't Go Away
}

\section{Citation}

Pinker, Steven. 2004. Why nature \& nurture won't go away. Daedalus 133(4): 5-17.

\section{Published Version}

doi:10.1162/0011526042365591

\section{Permanent link}

http://nrs.harvard.edu/urn-3:HUL.InstRepos:3600799

\section{Terms of Use}

This article was downloaded from Harvard University's DASH repository, and is made available under the terms and conditions applicable to Other Posted Material, as set forth at http:// nrs.harvard.edu/urn-3:HUL.InstRepos:dash.current.terms-of-use\#LAA

\section{Share Your Story}

The Harvard community has made this article openly available.

Please share how this access benefits you. Submit a story.

\section{Accessibility}




\section{Steven Pinker}

\section{Why nature \& nurture won't go away}

When Richard Mulcaster referred in 1581 to "that treasure ... bestowed on them by nature, to be bettered in them by nurture," he gave the world a euphonious name for an opposition that has been debated ever since. People's beliefs about the relative importance of heredity and environment affect their opinions on an astonishing range of topics. Do adolescents engage in violence because of the way their parents treated them early in life? Are people inherently aggressive and selfish, calling for a market economy and a strong police, or could they become peaceable and cooperative, allowing the state to wither and a spontaneous socialism to blossom? Is there a universal aesthetic that allows great art to transcend time and place, or are people's tastes determined by their era and culture? With so much seemingly at stake in so many fields, it is no surprise

Steven Pinker, Johnstone Family Professor in the department of psychology at Harvard University, conducts research on language and cognition. A Fellow of the American Academy since 1998, he is the author of six books, including "How the Mind Works" (1997), "The Language Instinct" (2000), and "The Blank Slate" (2002).

(C) 2004 by the American Academy of Arts \& Sciences that debates over nature and nurture evoke more rancor than just about any issue in the world of ideas.

During much of the twentieth century, a common position in this debate was to deny that human nature existed at all to aver, with José Ortega y Gasset, that "Man has no nature; what he has is history." The doctrine that the mind is a blank slate was not only a cornerstone of behaviorism in psychology and social constructionism in the social sciences, but also extended widely into mainstream intellectual life. ${ }^{1}$

Part of the blank slate's appeal came from the realization that many differences among people in different classes and ethnic groups that formerly were

1 Carl N. Degler, In Search of Human Nature: The Decline and Revival of Darwinism in American Social Thought (New York: Oxford University Press, 1991); Steven Pinker, The Blank Slate: The Modern Denial of Human Nature (New York: Viking, 2002); Robin Fox, The Search for Society: Quest for a Biosocial Science and Morality (New Brunswick, N.J. : Rutgers University Press, 1989); Eric M. Gander, On Our Minds: How Evolutionary Psychology Is Reshaping the Nature-Versus-Nurture Debate (Baltimore: Johns Hopkins University Press, 2003); John Tooby and Leda Cosmides, "The Psychological Foundations of Culture," in The Adapted Mind: Evolutionary Psychology and the Generation of Culture, ed. Jerome H. Barkow, Leda Cosmides, and John Tooby (New York: Oxford University Press, 1992). 
thought to reflect innate disparities in talent or temperament could vanish through immigration, social mobility, and cultural change. But another part of its appeal was political and moral. If nothing in the mind is innate, then differences among races, sexes, and classes can never be innate, making the blank slate the ultimate safeguard against racism, sexism, and class prejudice. Also, the doctrine ruled out the possibility that ignoble traits such as greed, prejudice, and aggression spring from human nature, and thus held out the hope of unlimited social progress.

Though human nature has been debated for as long as people have pondered their condition, it was inevitable that the debate would be transformed by the recent efflorescence of the sciences of mind, brain, genes, and evolution. One outcome has been to make the doctrine of the blank slate untenable. ${ }^{2}$ No one, of course, can deny the importance of learning and culture in all aspects of human life. But cognitive science has shown that there must be complex innate mechanisms for learning and culture to be possible in the first place. Evolutionary psychology has documented hundreds of universals that cut across the world's cultures, and has shown that many psychological traits (such as our taste for fatty foods, social status, and risky sexual liaisons) are better adapted to the evolutionary demands of an ancestral environment than to the actual demands of the current environment. Developmental psychology has shown

2 Pinker, The Blank Slate; Gary F. Marcus, The Birth of the Mind: How a Tiny Number of Genes Creates the Complexities of Human Thought (New York: Basic Books, 2004); Matt Ridley, Nature Via Nurture: Genes, Experience, and What Makes Us Human (London: Fourth Estate, 2003); Robert Plomin, Michael J. Owen, and Peter McGuffin, "The Genetic Basis of Complex Human Behaviors," Science 264 (1994): 1733-1739. that infants have a precocious grasp of objects, intentions, numbers, faces, tools, and language. Behavioral genetics has shown that temperament emerges early in life and remains fairly constant throughout the life span, that much of the variation among people within a culture comes from differences in genes, and that in some cases particular genes can be tied to aspects of cognition, language, and personality. Neuroscience has shown that the genome contains a rich tool kit of growth factors, axon guidance molecules, and cell adhesion molecules that help structure the brain during development, as well as mechanisms of plasticity that make learning possible.

These discoveries not only have shown that the innate organization of the brain cannot be ignored, but have also helped to reframe our very conception of nature and nurture.

$\mathrm{N}$ 1 ature and nurture, of course, are not alternatives. Learning itself must be accomplished by innate circuitry, and what is innate is not a set of rigid instructions for behavior but rather programs that take in information from the senses and give rise to new thoughts and actions. Language is a paradigm case: though particular languages such as Japanese and Yoruba are not innate, the capacity to acquire languages is a uniquely human talent. And once acquired, a language is not a fixed list of sentences, but a combinatorial algorithm allowing an infinite number of new thoughts to be expressed.

Moreover, because the mind is a complex system composed of many interacting parts, it makes no sense to ask whether humans are selfish or generous or nasty or noble across the board. Rather, they are driven by competing motives elicited in different circumstances. And 
if genes affect behavior, it is not by tugging on the muscles directly, but by their intricate effects on the circuitry of a growing brain.

Finally, questions of what people innately have in common must be distinguished from questions of how races, sexes, or individuals innately differ. Evolutionary biology gives reasons to believe that there are systematic specieswide universals, circumscribed ways in which the sexes differ, random quantitative variation among individuals, and few if any differences among races and ethnic groups. ${ }^{3}$

This reframing of human nature also offers a rational way to address the political and moral fears of human nature. 4 Political equality, for example, does not hinge on a dogma that people are innately indistinguishable, but on a commitment to treat them as individuals in spheres such as education and the criminal justice system. Social progress does not require that the mind be free of ignoble motives, only that it have other motives (such as the emotion of empathy and cognitive faculties that can learn from history) that can counteract them.

\section{$\mathrm{B}_{\text {y now most scientists reject both the }}$} nineteenth-century doctrine that biology is destiny and the twentieth-century doctrine that the mind is a blank slate. At the same time, many express a discomfort with any attempt to characterize the innate organization that the mind does have (even in service of a better understanding of learning). Instead,

3 John Tooby and Leda Cosmides, "On the Universality of Human Nature and the Uniqueness of the Individual: The Role of Genetics and Adaptation," Lournal of Personality 58 (1990): $17-67$.

4 Pinker, The Blank Slate. there is a widespread desire that the whole issue would somehow just go away. A common position on nature and nurture among contemporary scientists can be summarized as follows:

No one today believes that the mind is a blank slate; to refute such a belief is to tip over a straw man. All behavior is the product of an inextricable interaction between heredity and environment during development, so the answer to all nature-nurture questions is "some of each." If people only recognized this truism, the political recriminations could be avoided. Moreover, modern biology has made the very distinction between nature and nurture obsolete. Since a given set of genes can have different effects in different environments, there may always be an environment in which a supposed effect of the genes can be reversed or canceled; therefore the genes impose no significant constraints on behavior. Indeed, genes are expressed in response to environmental signals, so it is meaningless to try to distinguish genes and environments; doing so only gets in the way of productive research.

The attitude is often marked by words like 'interactionist,' 'developmentalist,' 'dialectic,' 'constructivist,' and 'epigenetic,' and is typically accompanied by a diagram with the labels 'genes,' 'behavior,' 'prenatal environment,' 'biochemical environment,' 'family environment,' 'school environment,' 'cultural environment,' and 'socioeconomic environment,' and arrows pointing from every label to every other label.

This doctrine, which I will call holistic interactionism, has considerable appeal. It is based on some unexceptionable points, such as that nature and nurture are not mutually exclusive, that genes cannot cause behavior directly, and that the direction of causation can go both 
ways (for example, school can make you smarter, and smart people are most engaged by schooling). It has a veneer of moderation, of conceptual sophistication, and of biological up-to-dateness. And as John Tooby and Leda Cosmides have put it, it promises "safe conduct across the politicized minefield of modern academic life." 5

But the very things that make holistic interactionism so appealing should also make us wary of it. No matter how complex an interaction is, it can be understood only by identifying the components and how they interact. Holistic interactionism can stand in the way of such understanding by dismissing any attempt to disentangle heredity and environment as uncouth. As Dan Dennett has satirized the attitude: "Surely 'everyone knows' that the nature-nurture debate was resolved long ago, and neither side wins since everything-is-a-mixtureof-both-and-it's-all-very-complicated, so let's think of something else, right?"

In the following pages I will analyze the tenets of holistic interactionism and show that they are not as reasonable or as obvious as they first appear.

“N position that the mind is a blank slate." Whether or not this is true among scientists, it is far from true in the rest of intellectual life. The prominent anthropologist Ashley Montagu, summing up a common understanding in twentiethcentury social science, wrote in 1973 that "With the exception of the instinctoid reactions in infants to sudden withdrawals of support and to sudden loud noises, the human being is entirely instinctless ....Man is man because he has no instincts, because everything he is and has become he has learned ... from

5 Tooby and Cosmides, "The Psychological Foundations of Culture." his culture, from the man-made part of the environment, from other human beings." 6 Postmodernism and social constructionism, which dominate many of the humanities, vigorously assert that human emotions, conceptual categories, and patterns of behavior (such as those characterizing men and women or homosexuals and heterosexuals) are social constructions. Even many humanists who are not postmodernists insist biology can provide no insight into human mind and behavior. The critic Louis Menand, for instance, recently wrote that "every aspect of life has a biological foundation in exactly the same sense, which is that unless it was biologically possible it wouldn't exist. After that, it's up for grabs."7

Nor is a belief in the blank slate absent among prominent scientists. Richard Lewontin, Leon Kamin, and Steven Rose, in a book entitled Not in Our Genes, asserted that "the only sensible thing to say about human nature is that it is 'in' that nature to construct its own history." 8 Stephen Jay Gould wrote that the "brain [is] capable of a full range of behaviors and predisposed to none." 9 Anne Fausto-Sterling expressed a common view of the origin of sex differences: "The key biological fact is that boys and girls have different genitalia,

6 Ashley Montagu, ed., Man and Aggression, 2nd ed. (New York: Oxford University Press, 1973).

7 Louis Menand, "What Comes Naturally," The New Yorker, 25 November 2002.

8 R. C. Lewontin, Steven Rose, and Leon J. Kamin, Not in Our Genes: Biology, Ideology, and Human Nature (New York: Pantheon Books, 1984).

9 Stephen Jay Gould, "Biological Potential vs. Biological Determinism," in Ever Since Darwin: Reflections in Natural History, ed. Stephen Jay Gould (New York: Norton, 1977). 
and it is this biological difference that leads adults to interact differently with different babies whom we conveniently color-code in pink or blue to make it unnecessary to go peering into their diapers for information about gender." 10

These opinions spill into research and policy. Much of the scientific consensus on parenting, for example, is based on studies that find a correlation between the behavior of parents and the behavior of children. Parents who spank have children who are more violent; authoritative parents (neither too permissive nor too punitive) have well-behaved children; parents who talk more to their children have children with better language skills. Virtually everyone concludes that the behavior of the parent causes the outcomes in the child. The possibility that the correlations may arise from shared genes is usually not even mentioned, let alone tested. ${ }^{11}$

Other examples abound. Many scientific organizations have endorsed the slogan "violence is learned behavior," and even biologically oriented scientists tend to treat violence as a public health problem like malnutrition or infectious disease. Unmentioned is the possibility that the strategic use of violence could have been selected for in human evolution, as it has been in the evolution of other primate species. ${ }^{12}$ Gender differences in the professions, such as that the proportion of mechanical engineers who

10 Anne Fausto-Sterling, Myths of Gender: Biological Theories About Women and Men (New York: Basic Books, 1985).

11 David C. Rowe, The Limits of Family Influence: Genes, Experience, and Behavior (New York: Guilford Press, 1994); Judith Rich Harris, The Nurture Assumption: Why Children Turn Out the Way They Do (New York: Free Press, 1998).

12 Martin Daly and Margo Wilson, Homicide (New York: A. de Gruyter, 1988). are women is less than 50 percent, are attributed entirely to prejudice and hidden barriers. The possibility that, on average, women might be less interested than men in people-free pursuits is similarly unspeakable. ${ }^{13}$ The point is not that we know that evolution or genetics are relevant to explaining these phenomena, but that the very possibility is often treated as an unmentionable taboo rather than as a testable hypothesis.

"F For every question about nature and nurture, the correct answer is 'some of each."” Not true. Why do people in England speak English and people in Japan speak Japanese? The 'reasonable compromise' would be that the people in England have genes that make it easier to learn English and the people in Japan have genes that make it easier to learn Japanese, but that both groups must be exposed to a language to acquire it at all. This compromise is, of course, not reasonable but false, as we see when children exposed to a given language acquire it equally quickly regardless of their racial ancestry. Though people may be genetically predisposed to learn language, they are not genetically predisposed, even in part, to learn a particular language; the explanation for why people in different countries speak differently is 100 percent environmental.

Sometimes the opposite extreme turns out to be correct. Psychiatrists commonly used to blame psychopathology on mothers. Autism was caused by 'refrigerator mothers' who did not emotionally engage their children, schizophrenia by mothers who put their children in double binds. Today we know that autism

13 David Lubinski and Camilla Benbow, "Gender Differences in Abilities and Preferences Among the Gifted: Implications for the MathScience Pipeline," Current Directions in Psychological Science 1 (1992): 61-66. 
and schizophrenia are highly heritable, and though they are not completely determined by genes, the other plausible contributors (such as toxins, pathogens, and developmental accidents) have nothing to do with how parents treat their children. Mothers don't deserve some of the blame if their children have these disorders, as a nature-nurture compromise would imply. They deserve none of it.

"If If people recognized that every aspect of behavior involves a combination of nature and nurture, the political disputes would evaporate." Certainly many psychologists strive for an innocuous middle ground. Consider this quotation:

If the reader is now convinced that either the genetic or environmental explanation has won out to the exclusion of the other, we have not done a sufficiently good job of presenting one side or the other. It seems highly likely to us that both genes and environment have something to do with this issue.

This appears to be a reasonable interactionist compromise that could not possibly incite controversy. But in fact it comes from one of the most incendiary books of the 1990s, Herrnstein and Murray's The Bell Curve. In this passage, Herrnstein and Murray summed up their argument that the difference in average IQ scores between American blacks and American whites has both genetic and environmental causes. A "some-ofeach" position did not protect them from accusations of racism and comparisons to Nazis. Nor, of course, did it establish their position was correct: as with the language a person speaks, the black-white average IQ gap could be 100 percent environmental. The point is that in this and many other domains of psy- chology, the possibility that heredity has any explanatory role at all is still inflammatory.

he effects of genes depend crucially on the environment, so heredity imposes no constraints on behavior." Two examples are commonly used to illustrate the point: different strains of corn may grow to different heights when equally irrigated, but a plant from the taller strain might end up shorter if it is deprived of water; and children with phenylketonuria (PKU), an inherited disorder resulting in retardation, can end up normal if given a diet low in the amino acid phenylalanine.

There is an aspect of this statement that indeed is worth stressing. Genes do not determine behavior like the roll of a player piano. Environmental interventions - from education and psychotherapy to historical changes in attitudes and political systems - can significantly affect human affairs. Also worth stressing is that genes and environments may interact in the statistician's sense, namely, that the effects of one can be exposed, multiplied, or reversed by the effects of the other, rather than merely summed with them. Two recent studies have identified single genes that are respectively associated with violence and depression, but have also shown that their effects are manifested only with particular histories of stressful experience. ${ }^{14}$

At the same time, it is misleading to invoke environment dependence to deny

14 Avshalom Caspi, Karen Sugden, Terrie E. Moffitt, Alan Taylor, and Ian W. Craig, "Influence of Life Stress on Depression : Moderation by a Polymorphism in the 5-HTT Gene," Science (2003): 386-389; Avshalom Caspi, Joseph McClay, Terrie E. Moffitt, Jonathan Mill, Judy Martin, and Ian W. Craig, "Evidence that the Cycle of Violence in Maltreated Children Depends on Genotype,” Science 297 (2002) : 727 742 . 
the importance of understanding the effects of genes. To begin with, it is simply not true that any gene can have any effect in some environment, with the implication that we can always design an environment to produce whatever outcome we value. Though some genetic effects may be nullified in certain environments, not all of them are: studies that measure both genetic and environmental similarity (such as adoption designs, where correlations with adoptive and biological parents can be compared) show numerous main effects of personality, intelligence, and behavior across a range of environmental variation. This is true even for the poster child of environmental mitigation, PKU. Though a low-phenylalanine diet does prevent severe mental retardation, it does not, as is ubiquitously claimed, render the person 'perfectly normal.' PKU children have mean IQs in the 80 and 90 and are impaired in tasks that depend on the prefrontal region of the cerebral cortex. ${ }^{15}$

Also, the mere existence of some environment that can reverse the expected effects of genes is almost meaningless. Just because extreme environments can disrupt a trait does not mean that the ordinary range of environments will modulate that trait, nor does it mean that the environment can explain the nature of the trait. Though unirrigated corn plants may shrivel, they won't grow arbitrarily high when given ever-increasing amounts of water. Nor does their dependence on water explain why they bear ears of corn as opposed to to-

15 Adele Diamond, "A Model System for Studying the Role of Dopamine in the Prefrontal Cortex During Early Development in Humans : Early and Continuously Treated Phenylketonuria," in Handbook of Developmental Cognitive Neuroscience, ed. Charles A. Nelson and Monica Luciana (Cambridge, Mass. : MIT Press, 2001). matoes or pinecones. Chinese foot-binding is an environmental manipulation that can radically affect the shape of the foot, but it would be misleading to deny that the anatomy of the human foot is in an important sense specified by the genes, or to attribute it in equal parts to heredity and environment. The point is not merely rhetorical. The fact that kittens' visual systems show abnormalities when their eyelids are sewn shut in a critical period of development does not imply (as was believed in the 1990s) that playing Mozart to babies or hanging colorful mobiles in their cribs will increase their intelligence. ${ }^{16}$

In short, the existence of environmental mitigations doesn't make the effects of the genes inconsequential. On the contrary, the genes specify what kinds of environmental manipulations will have what kinds of effects and with what costs. This is true at every level, from the expression of the genes themselves (as I will discuss below) to large-scale attempts at social change. The totalitarian Marxist states of the twentieth century often succeeded at modifying behavior, but at the cost of massive coercion, owing in part to mistaken assumptions about how easily human motives would respond to changed circumstances. ${ }^{17}$

Conversely, many kinds of genuine social progress succeeded by engaging specific aspects of human nature. Peter Singer observes that normal humans in

16 John T. Bruer, The Myth of the First Three Years: A New Understanding of Early Brain Development and Lifelong Learning (New York: Free Press, 1999).

17 Jonathan Glover, Humanity: A Moral History of the Twentieth Century (London: J. Cape, 1999); Peter Singer, A Darwinian Left: Politics, Evolution, and Cooperation (London: Weidenfeld \& Nicolson, 1999).
Why nature \& nurture won't go away 
all societies manifest a sense of sympathy: an ability to treat the interests of others as comparable to their own. ${ }^{18}$ Unfortunately, the size of the moral circle in which sympathy is extended is a free parameter. By default, people sympathize only with members of their own family, clan, or village, and treat anyone outside this circle as less than human. But under certain circumstances the circle can expand to other clans, tribes, races, or even species. An important way to understand moral progress, then, is to specify the triggers that prompt people to expand or contract their moral circles. It has been argued that the circle may be expanded to include people to whom one is bound by networks of reciprocal trade and interdependence, ${ }^{19}$ and that it may be contracted to exclude people who are seen in degrading circumstances. ${ }^{20}$ In each case, an understanding of nonobvious aspects of human nature reveals possible levers for humane social change.

${ }^{66}$ Genes are affected by their environments, and learning requires the expression of genes, so the nature-nurture distinction is meaningless." It is, of course, in the very nature of genes that they are not turned on all the time but are expressed and regulated by a variety of signals. These signals in turn may be triggered by a variety of inputs, including

\section{Peter Singer, The Expanding Circle: Ethics and Sociobiology (New York: Farrar, Straus \& Giroux, 1981).}

19 Robert Wright, NonZero: The Logic of Human Destiny (New York: Pantheon Books, 2000).

20 Glover, Humanity; Philip G. Zimbardo, Christina Maslach, and Craig Haney, "Reflections on the Stanford Prison Experiment: Genesis, Transformations, Consequences," in Obedience to Authority: Current Perspectives on the Milgram Paradigm, ed. Thomas Blass (Mahwah, N.J. : Lawrence Erlbaum Associates, 2000). temperature, hormones, the molecular environment, and neural activity. ${ }^{21}$ Among the environmentally sensitive gene-expression effects are those that make learning itself possible. Skills and memories are stored as physical changes at the synapse, and these changes require the expression of genes in response to patterns of neural activity.

These causal chains do not, however, render the nature-nurture distinction obsolete. What they do is force us to rethink the casual equation of 'nature' with genes and of 'nurture' with everything beyond the genes. Biologists have noted that the word 'gene' accumulated several meanings during the twentieth century. ${ }^{22}$ These include a unit of heredity, a specification of a part, a cause of a disease, a template for protein synthesis, a trigger of development, and a target of natural selection.

It is misleading, then, to equate the prescientific concept of human nature with 'the genes' and leave it at that, with the implication that environmentdependent gene activity proves that human nature is indefinitely modifiable by experience. Human nature is related to genes in terms of units of heredity, development, and evolution, particularly those units that exert a systematic and lasting effect on the wiring and chemistry of the brain. This is distinct from the most common use of the term 'gene' in molecular biology, namely, in reference to stretches of DNA that code for a

21 Marcus, The Birth of the Mind; Ridley, Nature Via Nurture.

22 Ridley, Nature Via Nurture; Richard Dawkins, The Extended Phenotype: The Gene as the Unit of Selection (San Francisco: W. H. Freeman \& Company, 1982); Seymour Benzer, "The Elementary Units of Heredity," in A Symposium on the Chemical Basis of Heredity, ed. William D. McElroy and Bentley Glass (Baltimore: Johns Hopkins Press, 1957). 
protein. Some aspects of human nature may be specified in information carriers other than protein templates, including the cytoplasm, noncoding regions of the genome that affect gene expression, properties of genes other than their sequence (such as how they are imprinted), and cross-generationally consistent aspects of the maternal environment that the genome has been shaped by natural selection to expect. Conversely, many genes direct the synthesis of proteins necessary for everyday metabolic function (such as wound repair, digestion, and memory formation) without embodying the traditional notion of human nature.

The various concepts of "environment,' too, have to be refined. In most nature-nurture debates, 'environment' refers in practice to aspects of the world that make up the perceptual input to the person and over which other humans have some control. This encompasses, for example, parental rewards and punishments, early enrichment, role models, education, laws, peer influence, culture, and social attitudes. It is misleading to blur 'environment' in the sense of the psychologically salient environment of the person with 'environment' in the sense of the chemical milieu of a chromosome or cell, especially when that milieu itself consists of the products of other genes and thus corresponds more closely to the traditional notion of heredity. There are still other senses of 'environment,' such as nutrition and environmental toxins; the point is not that one sense is primary, but that one should seek to distinguish each sense and characterize its effects precisely.

A final reason that the environment dependence of the genes does not vitiate the concept of human nature is that an environment can affect the organism in very different ways. Some aspects of the perceptual environment are instructive in the sense that their effects are predictable by the information contained in the input. Given a child who is equipped to learn words in the first place, the content of her vocabulary is predictable from the words spoken to her. Given an adult equipped to understand contingencies, the spot where he will park his car will depend on where the No Parking signs are posted. But other aspects of the environment, namely, those that affect the genes directly rather than affecting the brain through the senses, trigger genetically specified if-then contingencies that do not preserve information in the trigger itself. Such contingencies are pervasive in biological development, where many genes produce transcription factors and other molecules that set off cascades of expression of other genes. A good example is the Pax6 gene, which produces a protein that triggers the expression of twenty-five hundred other genes, resulting in the formation of the eye. Highly specific genetic responses can also occur when the organism interacts with its social environment, as when a change of social status in a male cichlid fish triggers the expression of more than fifty genes, which in turn alter its size, aggressiveness, and stress response. ${ }^{23}$ These are reminders both that innate organization cannot be equated with a lack of sensitivity to the environment, and that responses to the environment are often not specified by the stimulus but by the nature of the organism.

66 $\mathrm{F}$ Framing problems in terms of nature and nurture prevents us from understanding human development and mak-

23 Russell Fernald, "How Does Behavior Change the Brain? Multiple Methods to Answer Old Questions," Integrative Comparative Biology 43 (2003): $771-779$. 
ing new discoveries." On the contrary, some of the most provocative discoveries in twentieth-century psychology would have been impossible if there had not been a concerted effort to distinguish nature and nurture in human development.

For many decades psychologists have looked for the causes of individual differences in cognitive ability (as measured by IQ tests, school and job performance, and indices of brain activity) and in personality (as measured by questionnaires, ratings, psychiatric evaluations, and tallies of behavior such as divorce and crime). The conventional wisdom has been that such traits are strongly influenced by parenting practices and role models. But recall that this belief is based on flawed correlational studies that compare parents and children but forget to control for genetic relatedness.

Behavioral geneticists have remedied those flaws with studies of twins and adoptees, and have discovered that in fact virtually all behavioral traits are partly (though never completely) heritable. ${ }^{24}$ That is, some of the variation among individual people within a culture must be attributed to differences in their genes. The conclusion follows from repeated discoveries that identical twins reared apart (who share their genes but not their family environment) are highly similar; that ordinary identical twins (who share their environment and all their genes) are more similar than fraternal twins (who share their environment

24 Plomin, Owen, and McGuffin, "The Genetic Basis of Complex Human Behaviors"; Eric Turkheimer, "Three Laws of Behavior Genetics and What They Mean," Current Directions in Psvchological Science 9 (5) (2000): 160-164; Thomas J. Bouchard, Jr., "Genetic and Environmental Influences on Intelligence and Special Mental Abilities," Human Biology 70 (1998): $257-259$. but only half their variable genes); and that biological siblings (who share their environment and half their variable genes) are more similar than adoptive siblings (who share their environment but none of their variable genes). These studies have been replicated in large samples from several countries, and have ruled out the most common alternative explanations (such as selective placement of identical twins in similar adoptive homes). Of course, concrete behavioral traits that patently depend on content provided by the home or culture which language one speaks, which religion one practices, which political party one supports - are not heritable at all. But traits that reflect the underlying talents and temperaments - how proficient with language a person is, how religious, how liberal or conservative - are partially heritable. So genes play a role in making people different from their neighbors, and their environments play an equally important role.

At this point it is tempting to conclude that people are shaped both by genes and by family upbringing: how their parents treated them and what kind of home they grew up in. But the conclusion is unwarranted. Behavioral genetics allows one to distinguish two very different ways in which people's environments might affect them. The shared environment is what impinges on a person and his or her siblings alike: their parents, home life, and neighborhood. The unique environment is everything else: anything that happens to a person that does not necessarily happen to that person's siblings.

Remarkably, most studies of intelligence, personality, and behavior turn up few or no effects of the shared environment - often to the surprise of the researchers themselves, who thought it was obvious that nongenetic variation 
had to come from the family. ${ }^{25}$ First, adult siblings are about equally correlated whether they grew up together or apart. Second, adoptive siblings, when tested as adults, are generally no more similar than two people from the same culture chosen at random. And third, identical twins are no more similar than one would expect from the effects of their shared genes. Setting aside cases of extreme neglect or abuse, whatever experiences siblings share by growing up in the same home in a given culture make little or no difference to the kind of people they turn into. Specific skills like reading and playing a musical instrument, of course, can be imparted by parents, and parents obviously affect their children's happiness and the quality of family life. But they don't seem to determine their children's intellects, tastes, and personalities in the long run.

The discovery that the shared family environment has little to no lasting effect on personality and intelligence comes as a shock to the traditional wisdom that "as the twig is bent, so grows the branch." It casts doubt on forms of psychotherapy that seek the roots of an adult's dysfunction in the family environment, on theories that attribute adolescents' alcoholism, smoking, and delinquency to how they were treated in early childhood, and on the philosophy of parenting experts that parental micromanagement is the key to a well-adjusted child. The findings are so counterintuitive that one might doubt the behavioral genetic research that led to them, but they are corroborated by other

25 Rowe, The Limits of Family Influence; Harris, The Nurture Assumption; Turkheimer, "Three Laws of Behavior Genetics"; Robert Plomin and Denise Daniels, "Why Are Children in the Same Family So Different from One Another?" Behavioral and Brain Sciences 10 (1987): $1-60$. data. ${ }^{26}$ Children of immigrants end up with the language, accent, and mores of their peers, not of their parents. Wide variations in child-rearing practices day-care versus stay-at-home mothers, single versus multiple caregivers, samesex versus different-sex parents - have little lasting effect when other variables are controlled. Birth order and onlychild status also have few effects on behavior outside the home. ${ }^{27}$ And an extensive study testing the possibility that children might be shaped by unique aspects of how their parents treat them (as opposed to ways in which parents treat all their children alike) showed that differences in parenting within a family are effects, not causes, of differences among the children. ${ }^{28}$

T he discovery of the limits of family influence is not just a debunking exercise, but opens up important new questions. The finding that much of the variance in personality, intelligence, and behavior comes neither from the genes nor from the family environment raises the question of where it does come from. Judith Rich Harris has argued that the phenomena known as socialization - acquiring the skills and values needed to thrive in a given culture - take place in the peer group rather than the family.

26 Harris, The Nurture Assumption.

27 Ibid.; Judith Rich Harris, “Context-Specific Learning, Personality, and Birth Order," Current Directions in Psvchological Science 9 (2000): 174177 ; Jeremy Freese, Brian Powell, and Lala Carr Steelman, "Rebel Without a Cause or Effect: Birth Order and Social Attitudes," American Sociological Review 64 (1999): 207-231.

28 David Reiss, Jenae M. Neiderhiser, E. Mavis Hetherington, and Robert Plomin, The Relationship Code: Deciphering Genetic and Social Influences on Adolescent Development (Cambridge, Mass. : Harvard University Press, 2000). 
Though children are not prewired with cultural skills, they also are not indiscriminately shaped by their environment. One aspect of human nature directs children to figure out what is valued in their peer group - the social milieu in which they will eventually compete for status and mates - rather than to surrender to their parents' attempts to shape them.

Acknowledging this feature of human nature in turn raises questions about how the relevant environments, in this case peer cultures, arise and perpetuate themselves. Does a peer culture trickle down from adult culture? Does it originate from high-status individuals or groups and then proliferate along peer networks? Does it emerge haphazardly in different forms, some of which entrench themselves when they reach a tipping point of popularity?

A revised understanding of how children socialize themselves has practical implications as well. Teen alcoholism and smoking might be better addressed by understanding how these activities become status symbols in peer groups than by urging parents to talk more to their adolescents (as current advertisements, sponsored by beer and tobacco companies, insist). A major determinant of success in school might be whether classes fission into peer groups with different status criteria, in particular whether success in school is treated as admirable or as a sign of selling out. ${ }^{29}$

The development of personality - a person's emotional and behavioral idiosyncrasies - poses a set of puzzles distinct from those raised by the process of socialization. Identical twins growing up in the same home share their genes, their parents, their siblings, their peer groups, and their culture. Though they are high-

29 Harris, The Nurture Assumption. ly similar, they are far from indistinguishable: by most measures, correlations in their traits are in the neighborhood of 0.5. Peer influence cannot explain the differences, because identical twins largely share their peer groups. Instead, the unexplained variance in personality throws a spotlight on the role of sheer chance in development: random differences in prenatal blood supply and exposure to toxins, pathogens, hormones, and antibodies; random differences in the growth or adhesion of axons in the developing brain; random events in experience; random differences in how a stochastically functioning brain reacts to the same events in experience. Both popular and scientific explanations of behavior, accustomed to invoking genes, parents, and society, seldom acknowledge the enormous role that unpredictable factors must play in the development of an individual.

If chance in development is to explain the less-than-perfect similarity of identical twins, it also highlights an interesting property of development in general. One can imagine a developmental process in which millions of small chance events cancel one another out, leaving no difference in the resulting organism. One can imagine a different process in which a chance event could disrupt development entirely. Neither of these happens to identical twins. Their differences are detectable both in psychological testing and in everyday life, yet both are (usually) healthy human beings. The development of organisms must use complex feedback loops rather than prespecified blueprints. Random events can divert the trajectories of growth, but the trajectories are confined within an envelope of functioning designs for the species.

These profound questions are not about nature versus nurture. They are about nurture versus nurture: about 
what, precisely, are the nongenetic causes of personality and intelligence. But the puzzles would never have come to light if researchers had not first taken measures to factor out the influence of nature, by showing that correlations between parents and children cannot glibly be attributed to parenting but might be attributable to shared genes. That was the first step that led them to measure the possible effects of parenting empirically, rather than simply assuming that parents had to be all-powerful. The everything-affects-everything diagram turns out to be not sophisticated but dogmatic. The arrows emanating from 'parents,' 'siblings,' and 'the home' are testable hypotheses, not obvious truisms, and the tests might surprise us both by the arrows that shouldn't be there and by the labels and arrows we may have forgotten.

The human brain has been called the most complex object in the known universe. No doubt hypotheses that pit nature against nurture as a dichotomy or that correlate genes or environment with behavior without looking at the intervening brain will turn out to be simplistic or wrong. But that complexity does not mean we should fuzz up the issues by saying that it's all just too complicated to think about, or that some hypotheses should be treated a priori as obviously true, obviously false, or too dangerous to mention. As with inflation, cancer, and global warming, we have no choice but to try to disentangle the multiple causes. ${ }^{30}$

30 The writing of this paper was supported by NIH Grant HD-18381. I thank Helena Cronin, Jonathan Haidt, Judith Rich Harris, and Matt Ridley for comments on an earlier draft. 
This article has been cited by:

1. Matteo Mameli, David Papineau. 2007. The new nativism: a commentary on Gary Marcus's The birth of the mind. Biology \& Philosophy 21:4, 559-573. [CrossRef]

2. Robert J. Wyman. 2005. Experimental analysis of nature-nurture interactions. Journal of Experimental Zoology Part A: Comparative Experimental Biology 303A:6, 415-421. [CrossRef] 